\title{
CHAPTER 32 \\ THE MARCH 1962 STORM ON THE ATLANTIC COAST \\ OF THE UNITED STATES
}

\author{
M. P. O'Brien and J. W. Johnson \\ College of Engineering \\ University of California \\ Berkeley
}

Introduction

As far back as 1635, records show that the East Coast of the United States has repeatedly suffered from severe storm damage (McAleer, 1962). Most of these storms appear to have been of the hurricane type. Such storms generally form in the Atlantic to the east of the Bahama Islands and move eastward and then turn northward to sweep along the Atlantic Coast line (Fig. 1). Along the southern part of the Atlantic Coast the hurricanes move relatively slowly; damage results principally from flooding caused by direct wind action. North of Cape Hatteras the hurricanes move more rapidly (speeds of 40 to 50 miles per hour) and damage is largely due to sudden flooding from a rapidly moving storm surge (Simpson, 1962). The combination of storm surge, wind-driven water, and storm waves inundating large areas along the coast has on numerous occasions caused great damage and loss of life.

The great Atlantic Coast storm of March 1962, however, differed in character from the usual hurricane. It proved to be the most dis astrous winter coastal storm on record, causing damage from southern New England to Florida. This storm, of relatively large diameter and having gale force winds, remained nearly stationary off the Coast for almost 36 hours. The size and location of the storm, as further discussed below, was such that persistent strong northeasterly winds blowing over a relatively long fetch raised the spring tides (maximum range) to near-record levels. The tidal flooding which attended this storm was in many ways more disastrous than that which accompanies hurricanes (Cooperman and Rosendal, 1962). The storm surge in tropical cyclones generally recedes rapidly after one or two high tides, but the surge accompanying this storm occurred in many locations on four and five successive high tides! The great destruction was caused by high waves and breakers superimposed on these high tides.

In many ways the March 1962 storm was similar to the unusual and disastrous storm of February 1, 1953 in the Netherlands. This latter storm was different meteorologically than the usual North Sea gales that occur in this area. It had an extremely long duration and the 
COASTAL ENGINEERING
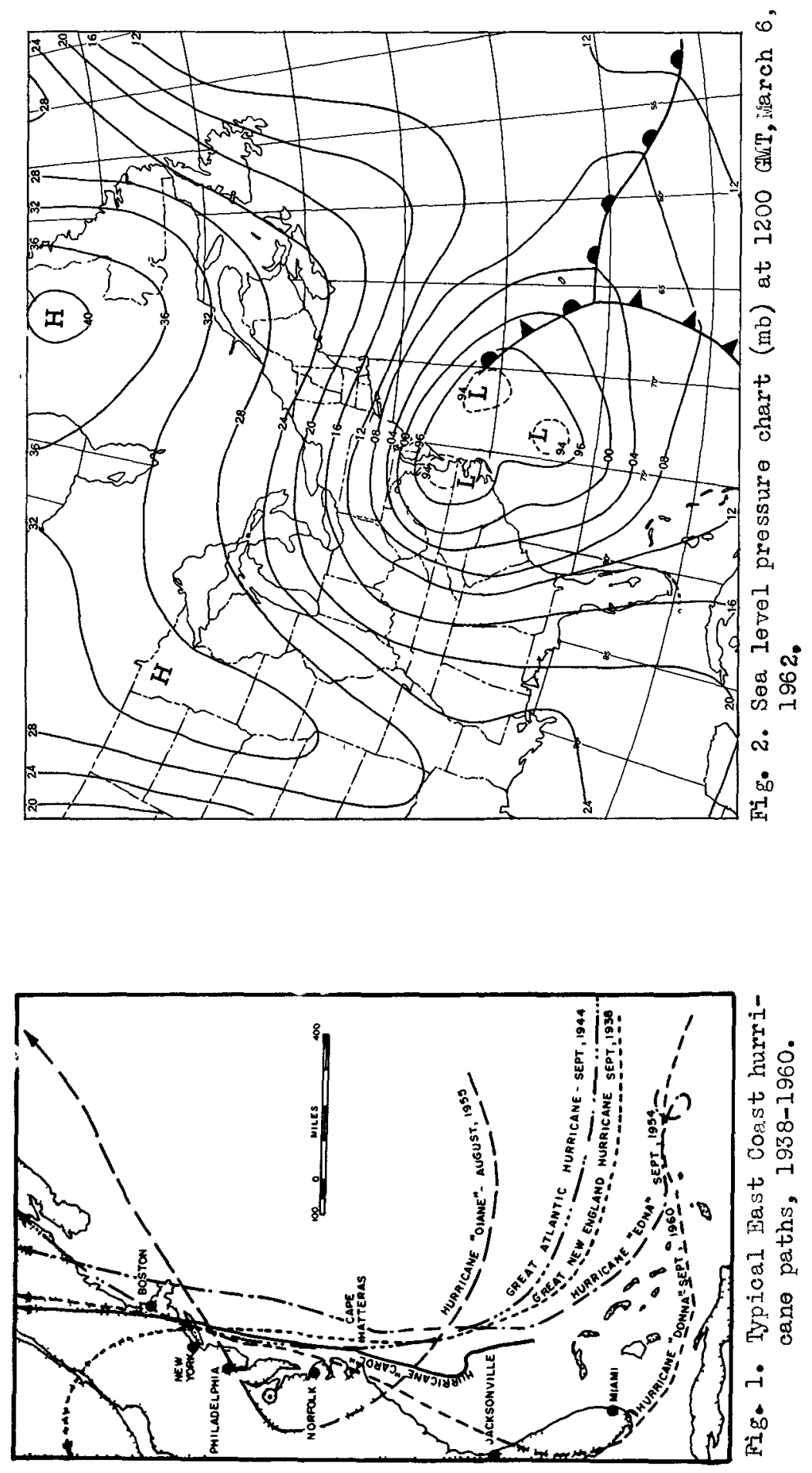


\section{THE MARCH 1962 STORM ON THE ATLANTIC COAST OF THE UNITED STATES}

track of the storm was very favorable for the generation of a high storm tide and high waves at critical locations along the Netherlands Coast (Wemelsfelder, 1953).

A broad factual summary of the principal features and results of the March 1962 storm follows.

\section{Meteorological Conditions}

On March 4, a weak circulation along a cold front started in the Atlantic east of Florida. Almost simultaneously a widespread but weak storm area was moving slowly eastward through the Mississippi Valley. On the following day these two storms deepened and partially merged (Cooperman and Rosendal, 1962; Anonymous, 1962). The offshore storm center continued to intensify on March 5 and 6 and slowly moved northward. On March 6 , the main center of the large storm, which actually consisted of a series of lows, stopped moving and became nearly stationary (Fig. 2). During this time the storm became elongated and, on March 7, appeared to have two centers (Fig. 3). The storm slowly moved eastward out into the Atlantic on the 7 th and 8 th. During this time, a gradually increasing fetch developed to the north between the center and New England (Fig. 3). Strong winds blowing over this fetch for a long time were responsible for raising the water level of the shore and generating waves of increasing heights. These large waves, breaking at a large angle to the shoreline of Long Island (Fig . 4), were particularly effective in removing large quantities of sand from the shore front and exposing the buildings and other improved property to a terrific battering over several high tides. Great swells from the extraordinary fetch occurring during the storm reached the South Atlantic States and caused substantial shore damage as far south as Miami Beach.

Of interest is a comparison between the March 6-8 storm and the usual hurricane. Although the March 1962 storm was not as intense as a hurricane, it had a lesser degree of symmetry, covered a much broader area, and was longer in duration, That is, the storm was roughly 1,500 miles in diameter compared to 600-700 miles for a hurricane.

\section{Wave Conditions}

Very little information on recorded wave data is available from this storm, since the only wave gage in the area (Atlantic City pier) was carried away early on the firgt day of the storm after recording waves approximately 12 feet in height. A summary of ship observations of wave conditions, however, was made by the U. S. Navy Fleet Weather Central and is shown in Figure 5. It is noted in this figure that on 


\section{COASTAL ENGINEERING}

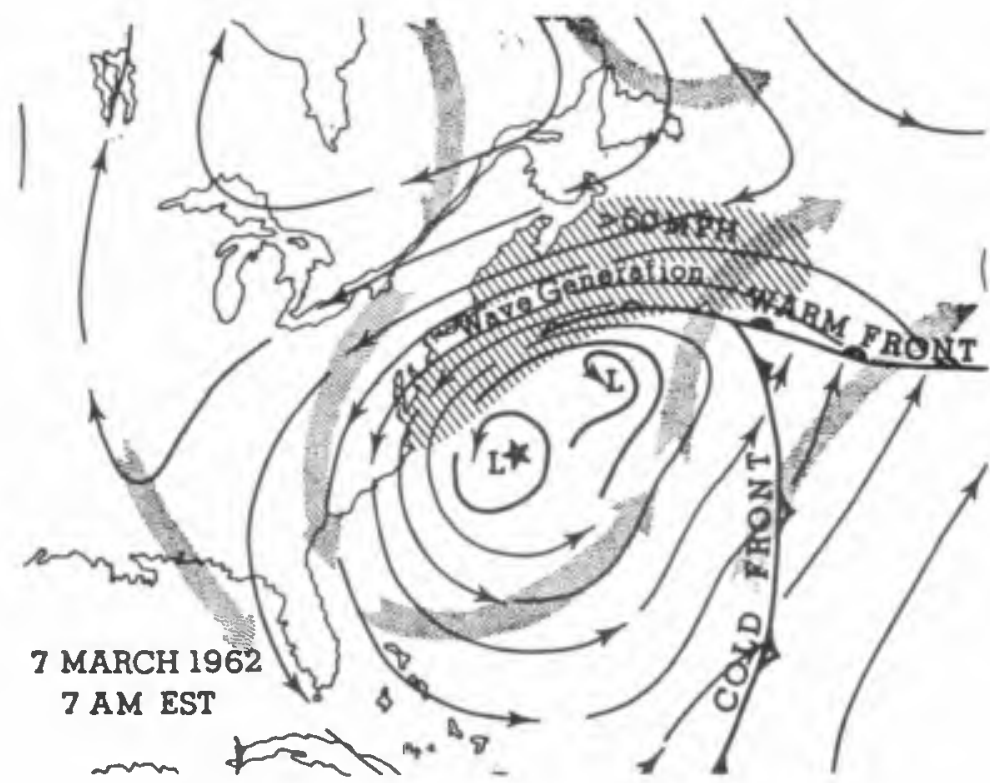

Fig. 3. Chart showing flow of surface winds (narrow arrows) acting over long fetch on Warch 7 . Broad arrows show flow of upper air.

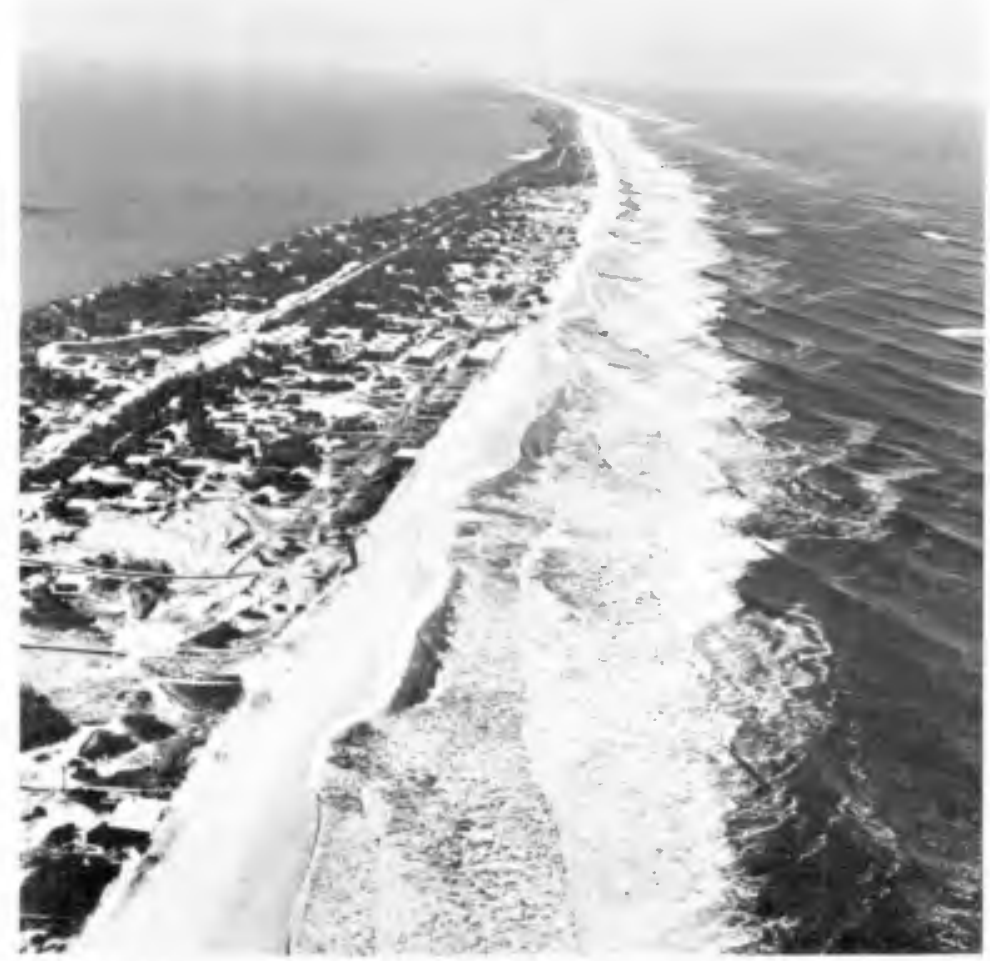

Fig. 4. Aerial view of Fire Island, N. Y. showing offshore bars and large angle of wave attack (Long Island State Park Commission). 


\section{THE MARCH 1962 STORM ON THE ATLANTIC COAST OF THE UNITED STATES}

March 8 the waves in the long fetch along the Northeastern States were 40 feet in height in deep water.

\section{Extreme Water Levels}

Although the extreme water levels at various localities along the Atlantic coast during the period of March 6-9 did not exceed the highest tide ever recorded, a near approach to the maximum did occur at many stations. Table 1, for example, lists for several stations the date and stage of the highest tide on record, the date, hour, and stage of tide in the March storm, and the feet that the stage in the March storm exceeded the predicted tide for the corresponding time.

TABIE 1

Summary of Extreme Water Levels Along the Atlantic Coast

(From U.S. Coast and Geodetic Survey)

\begin{tabular}{|c|c|c|c|c|c|c|}
\hline \multirow{4}{*}{ Location } & \multirow{2}{*}{\multicolumn{2}{|c|}{$\begin{array}{c}\text { Highest Tide on } \\
\text { Record }\end{array}$}} & \multirow{2}{*}{\multicolumn{4}{|c|}{$\begin{array}{c}\text { Extreme Water Levels } \\
\text { March 6-9, } 1962\end{array}$}} \\
\hline & & & & & & \\
\hline & & Feet & & Hour & Feet & Feet Above \\
\hline & Date & Above & Day & $\left(75^{\circ} \mathrm{W}\right)$ & Above & Predictions \\
\hline New Rochelle, N.Y. & & & $\overline{6}$ & $11: 00$ & 12.0 & 3.3 \\
\hline Montauk, N. Y. & & & 7 & $9: 36$ & 5.7 & 3.1 \\
\hline Eatons Neck, N.Y. & & & 6 & $23: 36$ & 11.6 & 3.4 \\
\hline Port Jefferson, N.Y & & & 6 & $23: 30$ & 10.9 & 3.3 \\
\hline Willets Point, N.Y. & & & 6 & $11: 18$ & 12.1 & 3.6 \\
\hline $\begin{array}{l}\text { New York (Battery), } \\
\text { N.Y. }\end{array}$ &, $9 / 12 / 60$ & 10.4 & 6 & $20: 54$ & 9.3 & 4.1 \\
\hline Sandy Hook, N.J. & $9 / 12 / 60$ & 10.6 & 6 & $20: 24$ & 9.9 & 4.5 \\
\hline Atlantic City, N.J. & $9 / 14 / 44$ & 9.5 & 6 & $7: 06$ & 9.1 & 3.9 \\
\hline Fort Miles, Del. & & & 6 & $21: 00$ & 9.7 & 4.9 \\
\hline Reedy Point, Del. & & & 8 & $00: 06$ & 9.4 & 3.3 \\
\hline Philadelphia, $\mathrm{Pa}$. & $11 / 25 / 50$ & 10.6 & 8 & $3: 12$ & 9.5 & 3.2 \\
\hline Washington, D.C. & $10 / 17 / 42$ & 11.5 & 8 & $8: 54$ & 6.4 & 3.1 \\
\hline Sewells Pt., Va. & & & 7 & $10: 00$ & 8.0 & 5.0 \\
\hline Portsmouth, Va. & & & 7 & $10: 24$ & 8.6 & 5.3 \\
\hline Wilmington, N.C. & & & 8 & $23: 54$ & 6.2 & 2.2 \\
\hline Myrtle Beach, S.C. & & & 8 & $21: 24$ & 8.2 & 2.2 \\
\hline Charleston, S.C. & $8 / 11 / 40$ & 10.7 & 8 & $22: 00$ & 8.2 & 2.2 \\
\hline Ft. Pulaski, Ga. & $10 / 15 / 47$ & 11.4 & 8 & $22: 06$ & 9.8 & 1.7 \\
\hline Fernandina, Fla. & $10 / 2 / 98$ & 13.9 & 8 & $23: 18$ & 8.4 & 1.6 \\
\hline Jacksonville, Fla. & & & 9 & $00: 24$ & 3.2 & 0.9 \\
\hline Mayport, Fla. & & & 8 & $22: 30$ & 6.5 & 1.3 \\
\hline Miami, Fla. & $10 / 18 / 50$ & 6.4 & 8 & $22: 00$ & 4.3 & 1.4 \\
\hline
\end{tabular}


COASTAL ENGINEERING
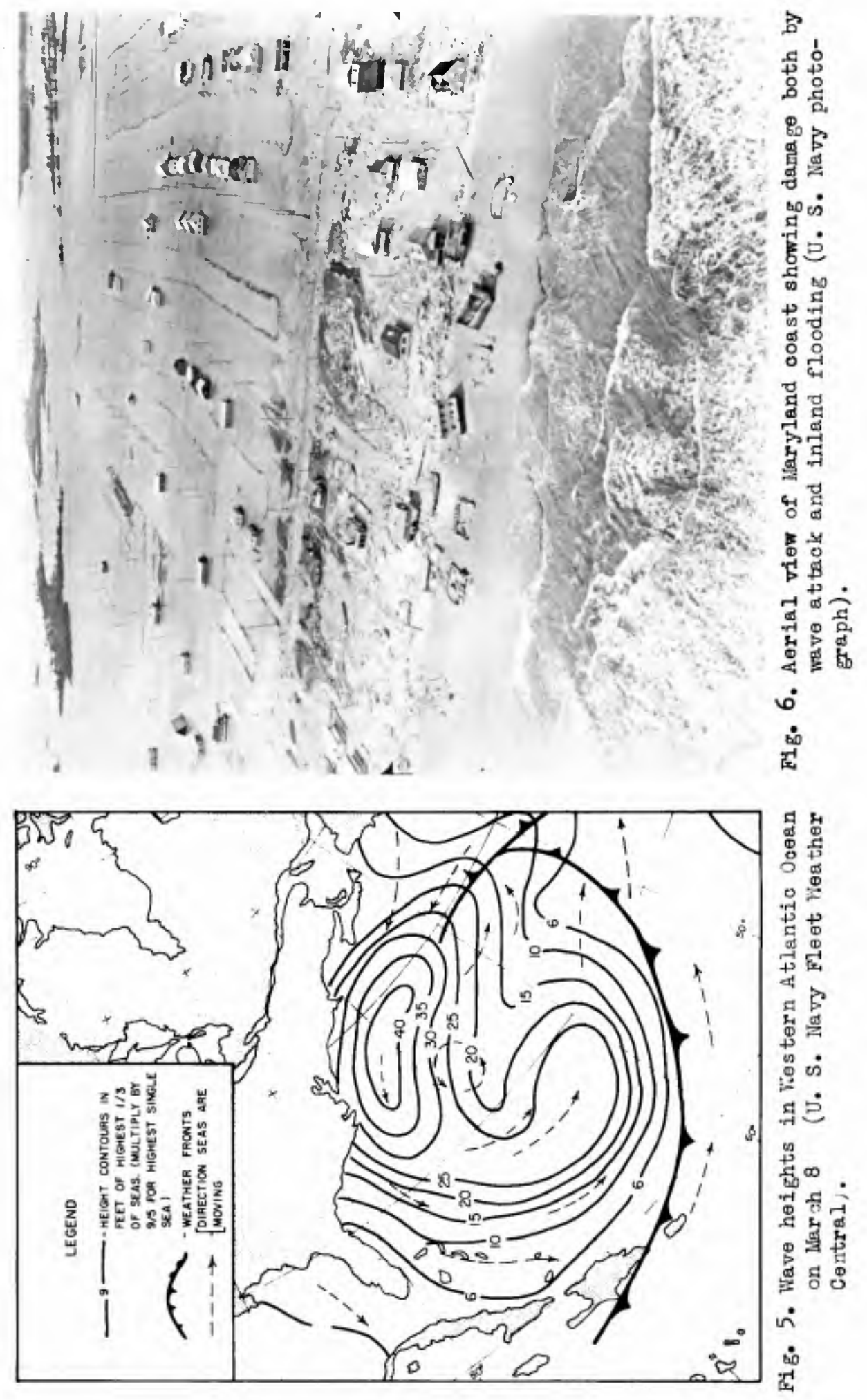


\section{THE MARCH 1962 STORM ON THE ATLANTIC COAST OF THE UNITED STATES}

In the New York area the tide stage almost equaled the highest on record which occurred during Hurricane "Donna" in September 1960; however, the damage during the March 6-9 storm was much more severe because of the long duration. That is, during Donna the high water occurred at only one high tide, after which the waters receded rapidly (Anonymous, 1962), but in the March storm damaging high waters occurred on five successive high tides over a period of 48 hours! Added to this were waves reported to be 20 to 30 feet high. Their momentum carried the water inland, and it reached houses and buildings which would ordinarily be beyond the reach of relatively high tides. Respite between successive high waters was only about 6 hours since flooding stages were maintained $2-3$ hours before and after high tide.

Along the New Jersey coast the tides were approximately equal to those in the September 1944 hurricane, but the recent storm lasted much longer.

In the Hampton Roads, Virginia, area the storm caused greater wave and flooding damage than any coastal storm of recent record, and in the outer banks of North Carolina the storm was as destructive as a major hurricane.

\section{General Character of Damage}

The March storm occurring at the peak of the spring tides and extending over five tides (generally 3 to 5 feet above normal--Table 1) with waves up to 30 feet high caused tremendous damage (Fig. 6) as a result of the protective sand beaches being destroyed (Cassidy, 1962). The effect of the heavy wave action was to remove sand from the beach face and deposit it as offshore underwater bars (Fig. 4). The waves then were able to overtop the berm or dune line, with water and sand sweeping across the barrier 1slands. Shoreline buildings thus were exposed to the full impact of wave and current action resulting in their total destruction in most instances (Fig. 6).

Strong tidal currents combined with the storm waves opened new inlets and eroded the sides of many existing inlets and moved sand through the inlets into the bays. The new inlets occurred at points where the barrier island was low and unprotected by a suitable dune or seawall. Because of the long duration of the storm, damage by flooding at inland localities not exposed to direct wave or current attack was considerable (Fig. 6). As a result of the many breaks in the line of dunes, large areas are now open to attack by storms of substantially less intensity than that of early March and immediate restoration of beaches and dunes in threatened areas is a necessity. It is of course also necessary to insure that once such shore protection is re-established it is not destroyed by leveling dunes at street ends or for the construction of homes 


\section{COASTAL ENGINEERING}

and business enterprises as has been done in the past (Anonymous, 1962). To summarize the damage problem the following statement by Cassidy (1962) is of importance:

"The physical damage was closely related not only to the general elevation of the shore but also to the adequacy of the dune, sea wall, and beach fronting the shore. In some areas wide beaches afforded good protection, and in others high dunes gave almost complete protection. Where there was insufficient beach and dune protection, severe damage resulted. In areas with the least protection beaches were completely eroded and shifted."

\section{REFERENCES}

1. Anonymous, East Coast Atlantic Storm, Preliminary Reports, Shore and Beach, Vol. 30, No. 1, April 1962, pp. 4-9.

2. Cassidy, W. F., Recovery operations after Atlantic Coast Storm, The Military Engineer, Vol. 54, No. 360, July-August 1962, pp. 246-248.

3. Cooperman, A. I. and Rosendal, H. E., Great Atlantic Storm, 1962, Mariners Weather Log, U. S. Dept. of Commerce, Vol. 6, No. 3, May 1962, pp. 79-85.

4. McAleer, J. B., Hurricane protection of Narragansett Bay, The Military Engineer, Vol. 54, No. 358, March-April 1962, pp. 112-115.

5. Simpson, R. H., Improvement of storm forecasting procedures, Hearings before Subcommittee on Oceanography of the Committee on Merchant Marine and Fisheries, House of Representatives, 87 th Cong., 2nd Sess., 1952, p. 20.

6. Wemelsfelder, P. J., The disaster in the Netherlands caused by the storm flood of February 1, 1953, Proc. Fourth Conference on Coastal Engin., 1954, pp 258-271. 